\title{
Assessment of onions contamination by pesticides residues and characterization of market gardeners' cultural practices in the region of Boucle du Mouhoun (Burkina Faso)
}

\author{
Roger DAKUYO ${ }^{1 *}$, Kiessoun KONATE ${ }^{1,2}$, Hemayoro SAMA $^{3}$, Abdoudramane SANOU ${ }^{1}$, \\ Kabakdé KABORE ${ }^{1}$, Mamounata DIAO ${ }^{1}$, Crépin Ibingou DIBALA ${ }^{1}$ and \\ Mamoudou Hama DICKO ${ }^{1}$ \\ ${ }^{1}$ Laboratory of Biochemistry, Food Biotechnology and Nutrition, Department of Biochemistry and \\ Microbiology, University Joseph KI-ZERBO, 03 BP 7021 Ouagadougou, Burkina Faso. \\ ${ }^{2}$ University of Dedougou, Burkina Faso. \\ ${ }^{3}$ Laboratory of Biochemistry and Applied Chemistry (LABIOCA), Department of Biochemistry and \\ Microbiology, University Joseph KI-ZERBO, 03 BP 7021 Ouagadougou, Burkina Faso. \\ *Corresponding author; E-mail : rogerdakuyo@gmail.com; Tel :00226 70793798.
}

\author{
Received: 16-07-2020 \\ Accepted: 25-09-2020 \\ Published: 31-12-2020
}

\begin{abstract}
This study was initiated in order to study cultural practices and assess levels of contamination in pesticide residues of onion samples produced in the region of Boucle du Mouhoun, Burkina Faso. A collection of samples was carried out at three gardening sites. A survey was also carried out to list the various pesticides used on market gardening sites and the practices for using pesticides. The QuEChERS method allowed the quantification of pesticides. The results show that $93 \%$ of the market gardeners were men, and more than $67 \%$ were between 25 and 35 years old. Nearly $55 \%$ of market gardeners are illiterate and do not have adequate means of protection when applying pesticides. A total of 16 pesticides have been accounted and most of them are Category II which are dangerous for human health and environment. 12 pesticide residues were quantified. Most of the active substances detected above the MRL (set by Codex Alimentarius and EU) were from the organochlorine family. These results reveal a fairly high level of contamination for pesticide residues. The study revealed that cultivation practices in market gardening sites as well as the consumption of onion pose numerous health risks for humans and the environment.
\end{abstract}

(C) 2020 International Formulae Group. All rights reserved.

Keywords: Onion cultivation, Human health, Market gardening, Environment.

\section{INTRODUCTION}

Market gardening in general and onion growing in particular contribute strongly to the fight against poverty by providing income for rural populations (Bako, 2011). Onion is a basic ingredient in culinary preparations in all regions of the world. The onion is a vegetable with food, nutritional and therapeutic virtues (Ouedraogo et al., 2015). It is considered nutritionally as an energizing, protective and supportive food, because it contains vitamins (B vitamins, vitamin $\mathrm{C}$, provitamin $\mathrm{A}$ ), 
minerals (potassium, sodium, etc.), lipids, proteins, carbohydrates, essential oils, acids and organic fibers (Konate et al., 2017, Donkor et al., 2016). In terms of therapeutic approaches, a number of studies have been carried out showed that regular consumption of raw onions would play a role in blood clotting, the prevention of various pathologies (atherosclerosis, cataract), of certain cardiovascular diseases and cancers (Lehmann et al., 2017).

The huge growth in agricultural and industrial production generated by the rapidly increasing human population and strong demand for commodities including onions has resulted in a dramatic increase in inputs of a wide range of artificial chemicals into the environment. Among these chemical pollutants, pesticides are very useful in controlling pests and diseases (Atmaca et al., 2019). Indeed, onion cultivation faces several biotic and/or abiotic constraints limiting its production. Pathogens are responsible for the estimated yield losses between $30 \%$ to $40 \%$ of the crop and are the main biotic constraints to production (Ouédraogo et al., 2016). In subSaharan Africa, crop and seed protection is mainly based on the use of chemical pesticides (Koala et al., 2018; Compaore et al., 2019).

Although chemical pesticides enable satisfactory results in agricultural production, their use is risky to human health, the environment and non-target organisms. This risk is higher because of the use in vegetable production of toxic and highly concentrated chemical pesticides intended to combat pests without appropriate protective equipment. Improper selection and use of pesticides on foodstuffs can result in undesirable levels of residues even after processing. Although, accidental intake, self-harm and occupational exposure are considered to be the major routes of exposure to pesticides in Burkina Faso (Toé, 2010). Dietary exposure is also an important source of contamination to pesticide residues (Jolliet et al., 2006). This food contamination is generally promoted by practices from the production chain to consumption. Hence pesticide residues in food might also constitute an important risk to human's health. To prevent health hazard and unnecessary exposure, Maximum Residue Limits (MRLs) and Admissible Daily Intake (ADI) have been implemented at national levels and internationally for example in the Codex Alimentarius (Lehmann et al., 2017).

Several studies (Son et al., 2017; Lehman et al., 2017) in Burkina Faso have highlighted the existence of poor phytosanitary practices in some gardening sites: failure to respect prescribed doses, failure to comply with the rules of protection and hygiene recommended during treatments, poor management of empty pesticide packaging. The consequences are the intoxication of farmers and consumers, environmental pollution and the development of pesticideresistant strains of pests (Bonner \& Alavanja, 2017). Indeed, although the use of these active substances brings benefits to agricultural production systems, it is important to mention their negative impact on the environment, human and animal health (Tiendrebeogo et al., 2017). In Burkina Faso, market gardening is practiced in various areas but unfortunately, data on the cultivation habits of market gardeners and products contamination levels are very limited, especially in areas such as Boucle du Mouhoun, which is one of the largest suppliers of vegetables in Burkina Faso. This study was therefore conducted among onion producers in Boucle du Mouhoun (Burkina Faso) to characterize farmers' cultural practices in market garden sites and assess onion contamination. The object of this paper is intended to draw the attention of producers and authorities to the risks associated in pesticides use and the necessity to apply the better phytosanitary practices.

\section{MATERIALS AND METHODS}

\section{Presentation of collection sites}

Samples were collected mainly at 2 market gardening sites (Lery and Di) and at the 
market of Dedougou. The market of Dedougou is the main outlet for agricultural products in the region. The Lery and Di market garden site and the market of Dedougou are located in the west of Burkina Faso in the region of Boucle du Mouhoun. Lery is a town in the province of Nayala located north of the city of Dedougou (capital of the region) about $40 \mathrm{~km}$. It abounds in one of the great shallows of the province. The market of Dedougou is located in the center of the city. It is the main commercial center of the city and thus allows a fluidity of exchanges. The main market gardening products in the Boucle du Mouhoun region are cabbage, onions, tomatoes, eggplants, green beans, etc. The market garden site of $\mathrm{Di}$ is located in the Boucle du Mouhoun region, precisely in the Sourou province. The populations benefit from collective and individual farming systems on areas developed (irrigated) by the State and other partners. The main vegetable crops grown are onion, tomato, eggplant, cucumber, lettuce or salad, cabbage, zucchini, pepper and chilli.

\section{Surveying and samples collection}

The investigation and samples collection were carried out during February and March 2019. The collection of samples was carried out at the two aforementioned production sites and at the Dedougou market. The collected material was composed of bulbs of onions. The collection concerned 15 groups of producers and 10 associations of vegetal products sellers. 25 samples have been collected in all. Each sample has been put into a freezing bag, labelled and all put into an icebox and has been sent to laboratory for analyses. In order to determinate farmer's demographic characteristics and cultivation practices, surveying has been made on their cultivation habits before the samples collection. The surveying consisted in an interview and permitted to obtain the sociodemographic characteristics and the cultivation habits of the market gardeners' groups. The survey also tackled the cultivation habits of the market gardeners. The settings retained for this study were the waiting period, the average doses applied by the producers, the pesticides packaging's management, the use of protective equipment during the treatment operations and the discomforts felt after the use of the plant protection products.

\section{Pesticides extraction}

Pesticides residues in onions were extracted using a modified AOAC 2007.01 QuEChERS (Quick Easy Cheap Rugged and Safe) extraction method (Borowiak et al., 2014). $10 \mathrm{~mL}$ of acetonitrile was added on $5 \mathrm{~g}$ of each sample in a tube falcon and vortexed for one min. The extraction of samples was realized by centrifugation $(3000 \mathrm{tr} / \mathrm{min}$ for $5 \mathrm{~min}$ ) with one (1) $\mathrm{g}$ of sodium chloride $(\mathrm{NaCl})$, one (1) $\mathrm{g}$ of sodium citrate $(\mathrm{Na}$ Citrate), $0.5 \mathrm{~g}$ of sodium citrate anhydrous $\left(\mathrm{Na}_{3} \mathrm{C}_{6} \mathrm{H}_{5} \mathrm{O}_{7}\right)$ centrifugation with salts (sulphate of anhydrous sodium) and carbon black graphitized (GCB) to mobilize the coloured substances (chlorophyl and carotene) that are non-active by precipitation. The supernatant obtained from the frozen extract after centrifugation was recovered in a vial using a Pasteur pipette.

\section{Gas chromatography analysis}

The analysis of the extracts was carried out using a chromatograph in gas phase (Agilent Technologies) that has a microdetector which captures electron (GC$\mu$ ECD/GC-FPD, Hewlett Packard). A capillary chromatographic column of type dB-17 MS. It had a length of $30 \mathrm{~cm}$, an internal diameter of $250 \mu \mathrm{m}$ and a thickness of $0.25 \mu \mathrm{m}$. Nitrogen of high purity was used as the carrier gas. The injection was carried out using Split/Splitless injection technique with an injection volume of $2 \mu \mathrm{l}$. The temperatures of the apparatus were as follows: - Room of injector programmed at 275 ${ }^{\circ} \mathrm{C}$ with a pressure of $20.72 \mathrm{psi}$; - Column (75 ${ }^{\circ} \mathrm{C}$ during $0.5 \mathrm{mn}, 75-300{ }^{\circ} \mathrm{C}$ with a flow of 10 ${ }^{\circ} \mathrm{C} / \mathrm{mn}$ and $300{ }^{\circ} \mathrm{C}$ during $7 \mathrm{mn}$ ); - Detector F.I.D (Flame Ionization Detector) $325^{\circ} \mathrm{C}$. 


\section{Statistical analysis}

The data have been entered in an Excel spreadsheet. The statistical analyses and the graphs have been created with the XLSTAT software version 2016 and GraphPad Prism 6.01 . The quantified residues were subjected to one-way analysis of variance (ANOVA) at the 5\% level. When the ANOVA test showed significant differences in the quantified pesticides, the Tukey test (at the 5\% threshold) was performed for the ranking of averages.

\section{RESULTS}

\section{Sociodemographic characteristics of the producers}

The sociodemographic characteristics of the producers of surveying sites are presented in Figure 1. The sociodemographic data recorded covered the sex, the age, the education level and the main occupation of the market gardeners. These data can hugely influence the market gardener's level of knowledge about plant protection products and justify their practices on market gardening sites. The results showed that the majority of the market gardeners are men (93\%) (Figure 2a) and $67 \%$ were young (age between 25 and 35 years) (Figure $2 b$ ). Also, more than $50 \%$ of the onion producers received no training (Figure 2c) and $3 / 4$ of them have agriculture as their first occupation (Figure 2d). The proportion of women holding some parcels and members of the market gardener's groups was very low, only $7 \%$ of the investigated market gardeners. A few of them are fisherwomen and others are housewives. The highest education level was secondary cycle. Indeed, $40 \%$ have primary school level and $10 \%$ did secondary studies. On the other hand, none of the producers has reached top level.

\section{Cultivation practices and health and environmental risks}

The recorded data show that the market gardeners do not respect the instructions of the pesticides recommended by the manufacturers during the phytosanitary treatments. Also, the majority (67\%) of producers asserted to do the treatments without particular equipment (Figure $3 a$ ). Only $33 \%$ of the market gardeners have protective equipment. This equipment was essentially composed of boots, mufflers and rarely blouses. The doses utilized varied from one group to another. The lowest dose was $0.15 \mathrm{~L} / \mathrm{ha}$ while the strongest one was 4 L/ha (Figure 3c). These doses were different from the ones mentioned on the packaging's by the manufacturer. The survey results also showed that the market gardeners do not have a standard management method of the packaging's. $80 \%$ of the producers abandoned the packaging's in nature either in field or anywhere else in the field surrounding and 7\% threw them in the river current. Only, $13 \%$ buried the rest and packaging in the soil (Figure $3 b) .75 \%$ of the market gardeners declared having felt discomfort (headache, nausea, dizziness etc.) after applying the pesticides. $67 \%$ of market gardeners reported harvesting the onions for consumption or sale starting one week, $20 \%$ two weeks after the last treatment. The longest time between the pesticides application and the harvest was one month and only $13 \%$ of the market gardeners respects this time (Figure 3d). Some of them proceeded to the harvest only four days after the pesticide's application. Most market gardeners (73\%) say they feel unwell after applying pesticides (Figure 3e).

\section{Types of pesticides used and risks on human health and environment pollution}

The main pesticides used in the phytosanitary treatment with their degree of toxicity recorded in the different market gardening sites of the study are presented in Table 1. A total of 15 pesticides have been identified in the two sites (Table 1). Most of the pesticides listed are Category II according to toxicity, which means that they are dangerous for human health and environment.

\section{Contamination level in pesticides residues of collected onion samples}

The samples collected on the vegetable sites and in the market have been analyzed in 
order to quantify the residues of pesticides in the bulbs of onions. The main active compounds detected and quantified are listed in the Table 2. A total of 12 active compounds belonging to the four big families of pesticides (organophosphate,

organochlorines, pyrethroids and carbamates) have been detected and quantified. Among these 12 residues quantified, 6 belong to the organophosphate family (68\%), 4 belong to the one of organochlorines (21\%), 2 belong to the one of pyrethroids $(6.33 \%)$ and only one belonged to the family of carbamates $(4.67 \%)$ for the two families (Figure 4).

Broadly, the highest concentrations have been found in the samples from the site of Lery. The alachlor has been detected with the largest concentration $(6.48 \mathrm{ppm})$ in the production site of Lery whereas some residues such as the parathion methyl, primiphos methyl, permethrin and tetramethrin were absent or presented some values inferior to the threshold of detection in several samples. The results of ANOVA analyses reveal significant variations between the samples from the two sites of production and also with those from the distribution market of Dedougou (Table 2). The contents are compared to the international standards concerning the Maximum Residue Limits (MRL). The MRL used in this study are those of the European Union and the World Health Organization. The molecules which show superior contents to the norms: pyrimiphos methyl, 2.4-DDT, alachlore, lindane and tetrametrine (Figure 5).

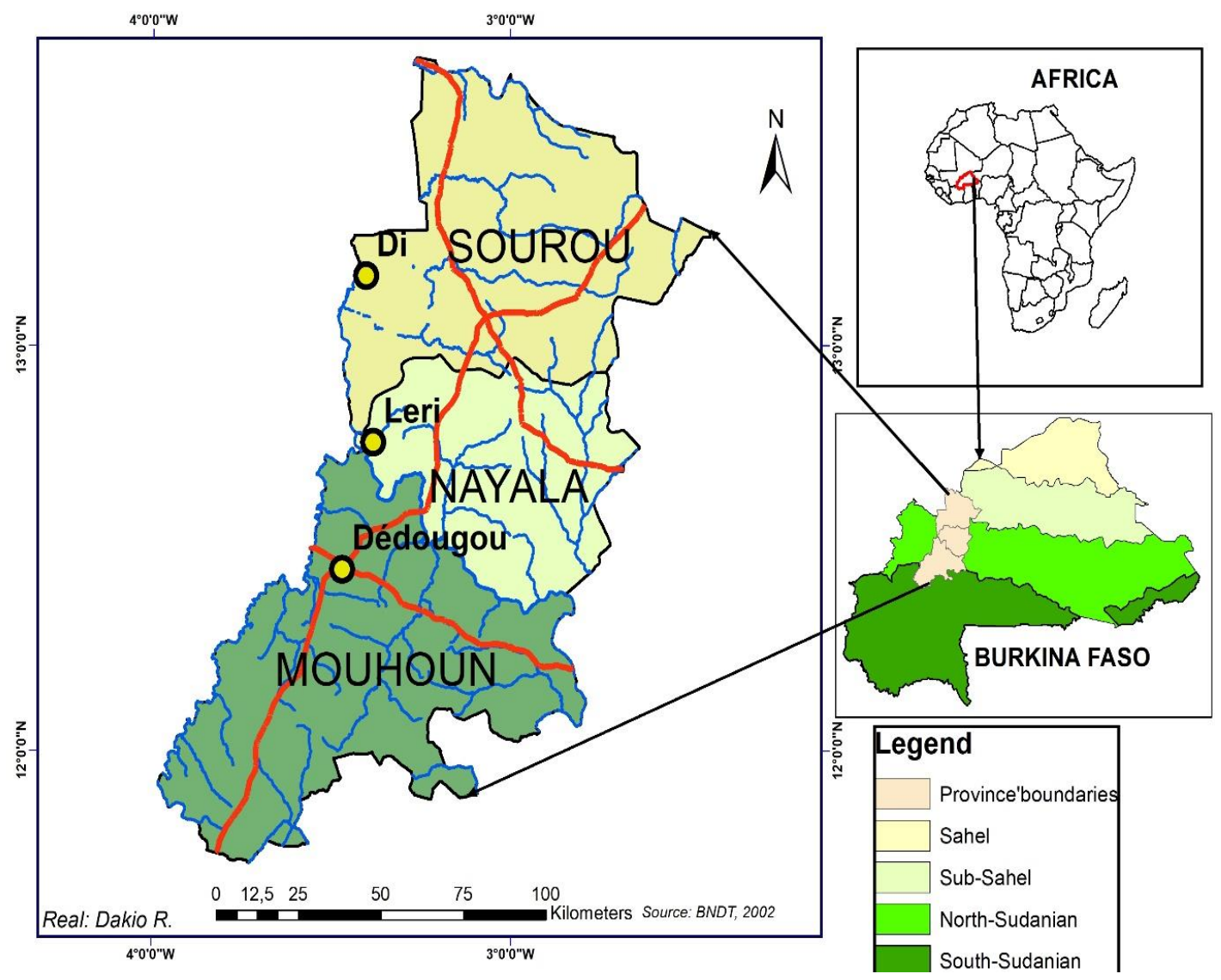

Figure 1 : Study area map. 


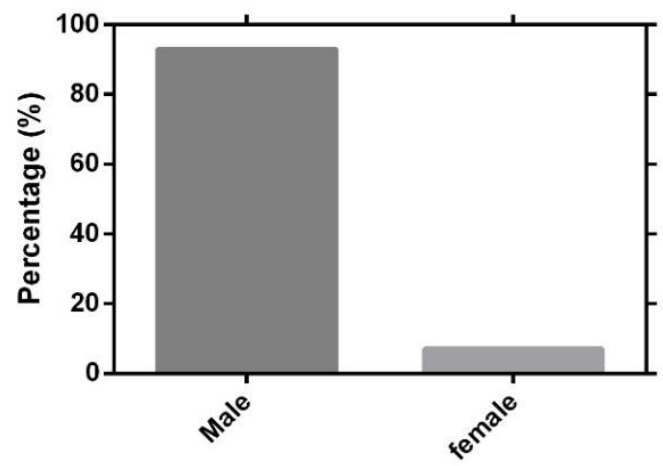

Fig.2.a: market gardeners' gender

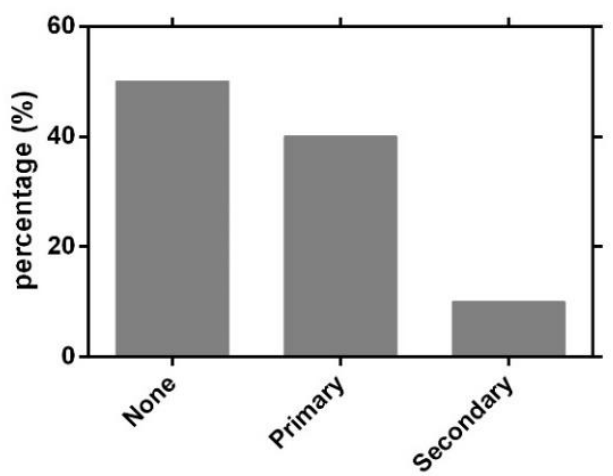

Fig.2.c: market gardeners' education level

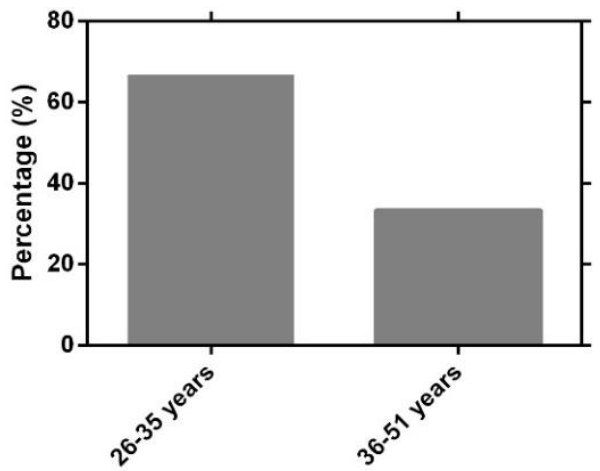

Fig.2.b: market gardeners' age group

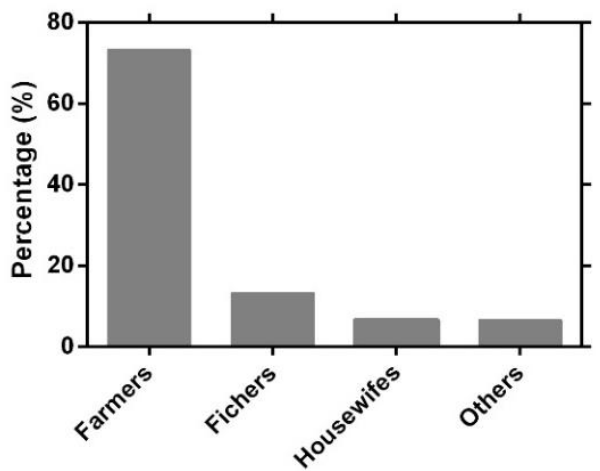

Fig.2.d: market gardeners' mainly occupation

Figure 2 : Market gardeners' socio-demographic characteristics.

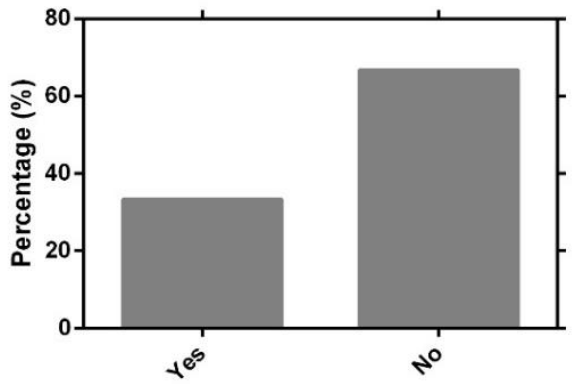

Fig.3.a: use of protective equipment

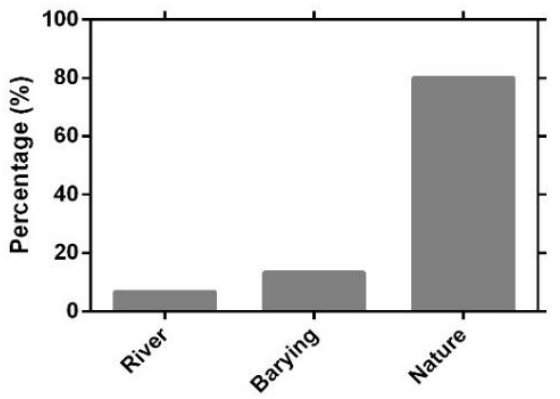

Fig.3.b: packaging management

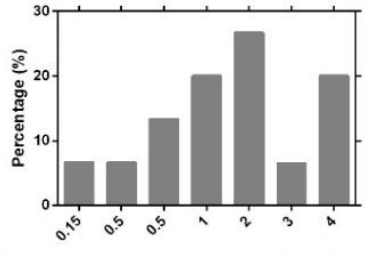

Fig.3.c: average doses used per treatment $(\mathrm{L} / \mathrm{Ha})$

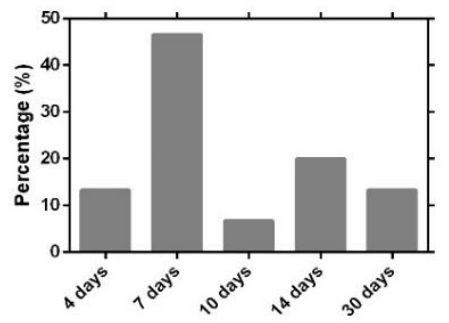

Fig.3.d: waiting time (days)

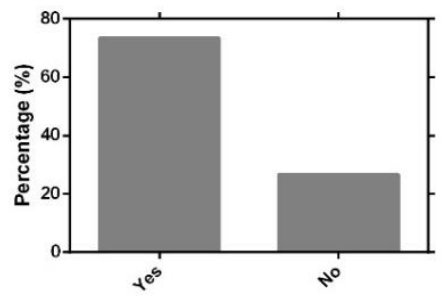

Fig.3.e: discomfort felt

Figure 3: Cultural habtits of market gardeners. 
Table 1 : Pesticides used in the Sourou valley and in Lery.

\begin{tabular}{lcc}
\hline Commercial name & Type of pesticides & Category of Toxicity \\
\hline ACARIUS 80 EC & Insecticide & II \\
\hline ACARICE 018 EC & Insecticide & II \\
\hline ADUMA WURA & Insecticide & II \\
\hline ATTAKAN 344 EC & Insecticide + herbicide & II \\
\hline CAIMAN ROUGE & Insecticide & II \\
\hline COGA 80 WP & Insecticide & II \\
\hline CYPERCAL 50 EC & Insecticide & II \\
\hline D-BAN SUPER & Insecticide & II \\
\hline DELTA CAL & Insecticide & II \\
\hline EMACOT & Insecticide & II \\
\hline FURADAN & Insecticide & Id \\
\hline LAMBDA super 25EC & Insecticide & II \\
\hline RAMBO & Insecticide & II \\
\hline ROUNDUP 360 SL & Insecticide & II \\
\hline THEORAL & Insecticide & II \\
\hline TITAN 25EC & Insecticide & II \\
\hline Id = highly dangerous; II $=$ dangerous & & \\
\hline
\end{tabular}

Table 2: Comparison of onions contamination by sites.

\begin{tabular}{lccc}
\hline Molecules (ppm) /areas & Lery & Dédougou market & Sourou \\
\hline Diazinonm & $0.067 \pm 0.012^{\mathrm{a}}$ & $0.045 \pm 0.025^{\mathrm{b}}$ & $0.060 \pm 0.020^{\mathrm{a}}$ \\
\hline Dimethoate & $0.102 \pm 0.075^{\mathrm{b}}$ & $0.125 \pm 0.022^{\mathrm{a}}$ & $0.043 \pm 0.013^{\mathrm{c}}$ \\
\hline Fenitrothion & $0.040 \pm 0.015^{\mathrm{b}}$ & $0.075 \pm 0.032^{\mathrm{a}}$ & $0.0460 .025^{\mathrm{b}}$ \\
\hline Parathion methyl & $0.163 \pm 0.090^{\mathrm{a}}$ & $0.110 \pm 0.070^{\mathrm{b}}$ & $0.036 \pm 0.018^{\mathrm{c}}$ \\
\hline Pirimiphos methyl & $0.102 \pm 0.095^{\mathrm{a}}$ & $0.082 \pm 0.028^{\mathrm{b}}$ & $0.000 \pm 0.000^{\mathrm{c}}$ \\
\hline Profenofos & $0.062 \pm 0.014^{\mathrm{b}}$ & $0.141 \pm 0.081^{\mathrm{a}}$ & $0.000 \pm 0.000^{\mathrm{c}}$ \\
\hline 2,4-DDT & $0.327 \pm 0.096^{\mathrm{b}}$ & $0.296 \pm 0.085^{\mathrm{b}}$ & $0.521 \pm 0.320^{\mathrm{a}}$ \\
\hline Alachlore & $6.478 \pm 2.200^{\mathrm{a}}$ & $0.892 \pm 0.325^{\mathrm{c}}$ & $2.156 \pm 0.865^{\mathrm{b}}$ \\
\hline Lindane & $0.453 \pm 0.150^{\mathrm{a}}$ & $0.311 \pm 0.100^{\mathrm{b}}$ & $0.144 \pm 0.076^{\mathrm{c}}$ \\
\hline Imazalil & $0.020 \pm 0.005^{\mathrm{c}}$ & $0.197 \pm 0.074^{\mathrm{a}}$ & $0.084 \pm 0.038^{\mathrm{b}}$ \\
\hline Permetrine & $0.000 \pm 0.000^{\mathrm{b}}$ & $0.000 \pm 0.000^{\mathrm{b}}$ & $0.137 \pm 0.091^{\mathrm{a}}$ \\
\hline Tetrametrine & $3.584 \pm 1.955^{\mathrm{a}}$ & $0.458 \pm 0.088^{\mathrm{b}}$ & $0.000 \pm 0.000^{\mathrm{c}}$ \\
\hline
\end{tabular}

ppm: $\mathrm{mg} / \mathrm{L}$ 


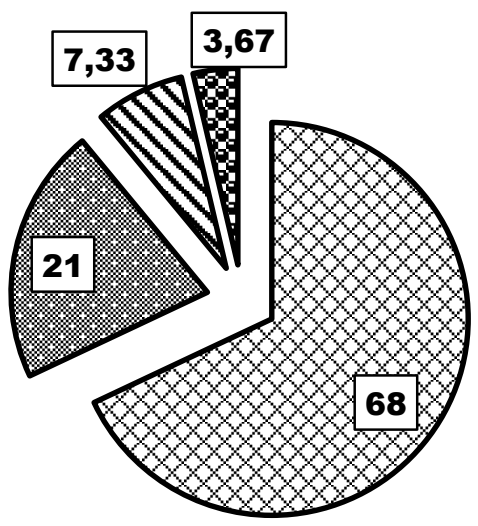

$\boldsymbol{\square}$ organophosphates $\boldsymbol{\otimes}$ organochlorines $\mathbf{\square}$ pyrethroids $\mathbf{\square}$ carbamates

Figure 4 : Percentage of pesticide families.

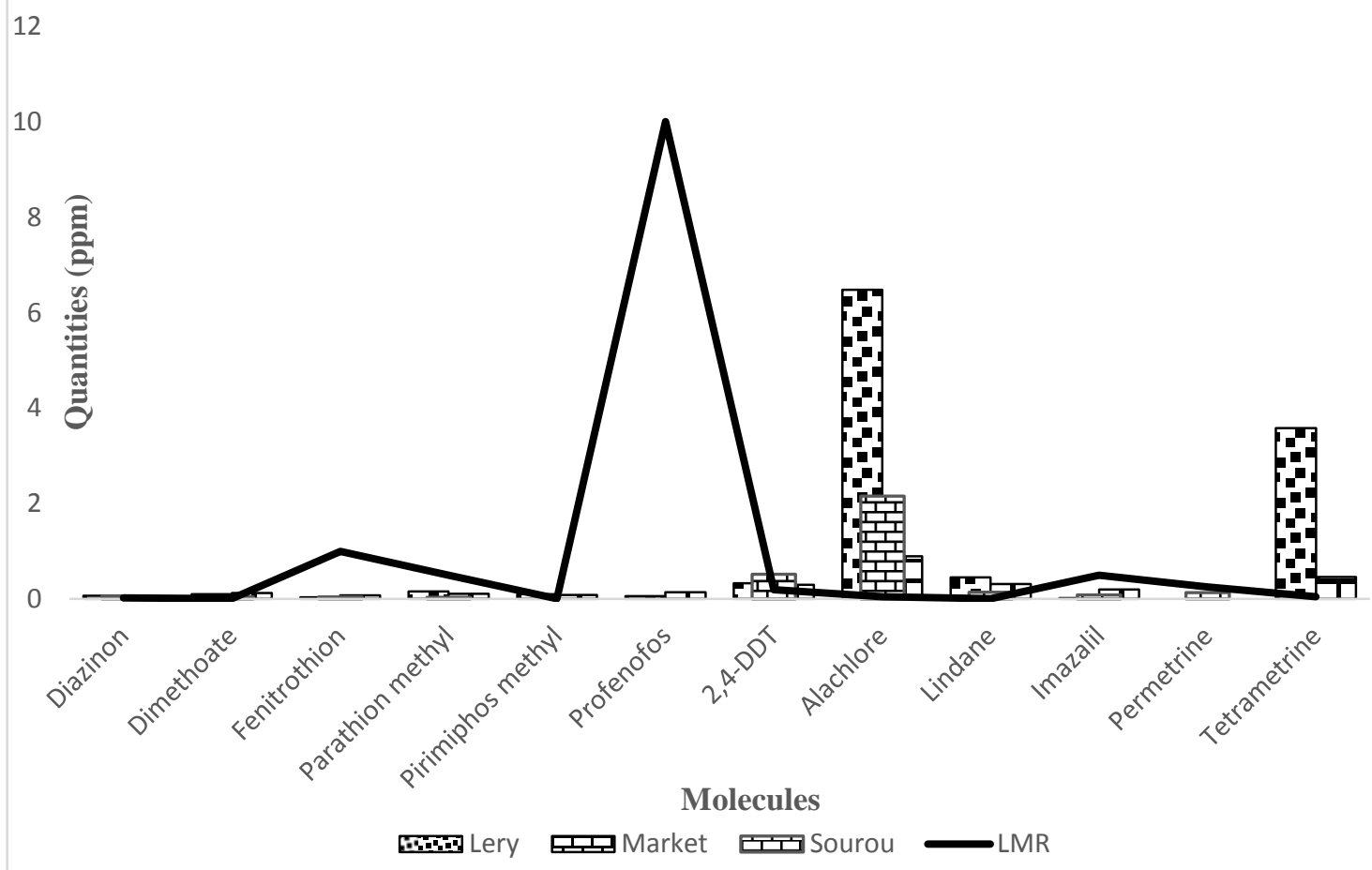

Figure 5 : Comparison of concentrations with MRL. 


\section{DISCUSSION}

Investigations and samples collection were carried out on market gardening sites of the region of Boucle du Mouhoun and at the market of Dedougou with the aim to characterize producers' cultivation practices and contamination levels of onion samples in order to assess their impact on human health and environmental. The investigations revealed that the onion production in the region of Boucle du Mouhoun is an activity mainly practiced by a predominantly illiterate population with an insufficient level of training and monitoring with predominance of young people. Our study revealed that more than half (53\%) of the population cannot read. These results corroborated those of Sawadogo (2016) and Congo (2013) in Burkina Faso who found respectively that more than 57 and $77.18 \%$ of market gardeners were illiterate. Illiteracy and lack of training limit the respect of good practices in pesticide use, including doses the wearing of equipment, and the method of preparation and pesticide use. indeed, the grower normally uses product labels to understand and follow the instructions on the boxes of pesticides used for weed control. Similar results were reported by Son et al. (2018) who also reported that the level of education is a determining factor for the mode of application, the persistence, the respect of the expiration times as well as the precautions to be taken before, during and after the application of pesticides. According to Kanda's group (2013) and Wognin et al. (2014), pesticide use requires a minimum of theoretical and practical knowledge to avoid health and environmental risks. Indeed, in the context of the use of pesticides, the doses and instructions for use must be respected. The relative youthfulness of market gardeners could be explained by the lack of work in the dry season, which leads many young people to work in market gardening to meet family needs. Socio-cultural considerations may also explain the youth of market gardeners (Tchamadeu et al., 2017; Shafiwu et al., 2018). The study also revealed that very few women are involved in market gardening. This difference can be explained by the sociological perceptions of different communities with regard to the place of women. In general, women do not own land and are therefore very poorly represented on the agricultural chessboard. However, they are the most active labour force in transplanting, weeding and harvesting onions (Diop et al., 2016). They are still at the top of the marketing chain. The analphabetism of the majority of market gardeners and their not being monitored by qualified people poses a real problem in the use of pesticides.

The study also reported treatments were carried out without adequate protective equipment, non-respect of doses and preharvest deadlines and the use of unsuitable products. In addition, the packages are thrown into the irrigation canals or into nature. Such practices pose many ecological and human health problems. Indeed, unintended exposure to pesticides can be extremely hazardous to humans and other living organisms. Nontarget pesticide poisoning has been reported from fish, birds, and humans. Kim et al. (2017) reported that pesticides is related to various diseases including cancers, leukemia, and asthma. The risk of health hazards due to pesticide exposure depends not only on how toxic the substances are but also on the level of exposure. In addition, some people such as children, pregnant women, or aging populations may be more sensitive to the effects of pesticides than others. Also, as some water reservoirs may be used for fish farming, there is a risk of contamination of humans through the transfer of pesticide residues as observed in Benin in through tilapia under similar conditions (Agbohessi et al., 2012). Additionally, many pesticides can persist for long periods in an ecosystem; organochlorine insecticides, for instance, are still detectable in surface waters 30 years after their use and had been banned.

The quantitative analysis of pesticide residues in the collected onion samples made it possible to detect and quantify active molecules. These active compounds belong to pyrethroids organophosphates, nitrogen and organochlorines families. The organophosphorus family was the most 
representative among the detected active molecules. Similar studies carried out by Ngom et al. (2013) on the evaluation of pesticides residues in the horticultural products consumed in Senegal detected residues of pesticides from organophosphorus compounds, in onion leaves and in headed cabbage. Also, most of the quantified active compounds were found simultaneously in the samples from the Lery and Sourou valley sites and also in the market samples. Our results corroborated those of Tarnagda et al. (2017) who reported the presence of residues of these families in leafy vegetables from the city of Ouagadougou. This situation results from the inappropriate or abusive use of pesticides and from the lack of environmental education for farmers (Licciardi et al., 2007). However, our results are in contrast to those of Son et al. (2017) and Tarnagda et al. (2019) who reported respectively that pyrethroid and organochlorines are the predominant families. Those differences could be explained by the diversity of pesticides used depending on the crop areas. The presence on the production sites of organophosphorus active compounds, which are strictly prohibited by the Sahelian committee of pesticides because of their toxicity, demonstrates the existence of fraud in the local pesticide trade (Guo et al., 2018). The simultaneously presence of the active's compounds in the 3 collected sites can mean that the market gardeners used the same pesticides or pesticides containing the same active compounds and also that the majority of onions sold in Dedougou markets come from these sites. Some residues such as 2,4-DDT, alachlor, lindane and tetramethrin are detected beyond the maximum residue limits (MRL) of the Codex Alimentarius and the EU, which constitutes a danger for consumers of onions. Consumption of products containing pesticide residues below the standards can cause consumers to have diseases such as cancer, asthma, Parkinson's disease, leukemia, cognitive effects and other side effects (Kim et al., 2017; Bonner and Alavanja, 2017). Ullah et al. (2016) also reported that animal studies have suggested that exposure to their pesticides may induce abdominal obesity, impair insulin sensitivity and reduce glucose uptake.

\section{Conclusion}

This study aimed at characterizing market gardening practices and to assess onion contamination levels and their impact on human health and the environment. The study recorded many bad practices that could be explained by the low level of education, training and monitoring of the practices. Such practices pose many risks to the health of producers and the environment. In addition, chemical analyses carried out on market gardening sites and at the Dedougou market, the main disposal site for market garden produce, made it possible to detect and quantify certain residues at values above the MRL. The consumption of onions at these levels of contamination because of the toxicity of pesticides exposes producers to many health risks including cancer, asthma, Parkinson's disease, leukemia, cognitive effects and other side effects. These practices also pose numerous risks of contamination to the environment and non-target organisms. To promote the rational management of pesticides and limit their impact on human health and the environment in Burkina Faso, it is necessary to reduce and control the use of pesticides by training and regular monitoring of market gardeners.

\section{COMPETING INTERESTS}

The authors declare that there is no competing interest.

\section{AUTHORS' CONTRIBUTIONS}

This work was carried out in collaboration with all authors. DR and KK designed the study and wrote the protocols. DR, SH, SA and KK, conducted experimentation and statistical analysis. DR and $\mathrm{SH}$ wrote the first draft of the manuscript. DM, DIC and KK corrected the first draft, made some technical inputs and came out with the final draft. KK and DHM managed the study and designed the journal. All authors read and approved the final manuscript. 


\section{ACKNOWLEDGEMENTS}

We thank the "Réseau ouest Africain des Biotechnologies" (RABiotech, ISP / IPICS project) for supporting academic mobilities and publication fees.

\section{REFERENCES}

Agbohessi TP, Toko II, N'tchaI, Geay F, Mandiki SNM, Kestemont P 2014. Exposure to agricultural pesticides impairs growth, feed utilization and energy budget in African Catfish Clarias gariepinus (Burchell, 1822) fingerlings. International Aquatic Research, 6(4): 229- 243.

DOI:

https://doi.org/10.1007/s40071-0140083-5.

Atmaca E, Das YK, Yavuz O, Aksoy A. 2019. An evaluation of the levels of organochlorine compounds (OCPs and PCBs) in cultured freshwater and wild sea fish eggs as an exposure biomarker for environmental contamination. Environmental Science and Pollution Research, 26(7): 7005-7012. DOI : https://doi.org/10.1007/s11356-01904207-0

Bako, D. 2011. «Financement de l'agriculture et croissance agricole: cas du Burkina Faso» articles de la DPSAA à des conférences scientifiques, janvier, 3-24. https://www.memoireonline.com/03/17/9 681/m_Agriculture-et-croissanceeconomique-dans-les-pays-de-laCEMAC 38.html

Bonner MR, Alavanja MCR. 2017. Pesticides, human health, and food security. Food and Energy Security, 6(3): 89-93. DOI : https://doi.org/10.1002/fes3.112

Borowiak K, Zbierska J, Barałkiewicz D, Hanć A, Budka A, Kayzer D, Kawala A. 2014. Biomonitoring of air pollution by trace elements using Italian ryegrass (Lolium multiflorum L. 'Lema'). Polish Journal of Environmental Studies, $\mathbf{2 3}(3)$ : 681- 688.

Compaoré $\mathrm{H}$, Ilboudo $\mathrm{S}$, Bama-Nati $\mathrm{AD}$, Balima Dama MM. 2019. Les risques sanitaires liés à l'utilisation des pesticides dans les bas-fonds rizicoles de la commune de Dano, province du Ioba Burkina Faso. African Crop Science Journal, 27(4): 557-569. DOI : https://doi.org/10.1017/CBO9781107415 324.004.

Congo AK. 2013. Risques sanitaires associés à l'utilisation des pesticides auttour de petites retenues: cas du barrage de Lombila. In Mémoire master 2iE (p. 68). http://documentation.2ieedu.org/cdi2ie/opac_css/doc_num.php?e xplnum_id=1825

Diop A, Diop YM, Thiaré DD, Cazier F, Sarr SO, Kasprowiak A, Landy D, Delattre F. 2016. Monitoring survey of the use patterns and pesticide residues on vegetables in the Niayes zone, Senegal. Chemosphere, 144: 1715-1721. DOI : https://doi.org/10.1016/j.chemosphere.20 15.10.058

Donkor A, Osei-Fosu P, Dubey B, KingsfordAdaboh R, Ziwu, C, Asante I. 2016. Pesticide residues in fruits and vegetables in Ghana: a review. Environmental Science and Pollution Research, 23(19), 18966- 18987.

DOI: https://doi.org/10.1007/s11356-0167317-6

Guo J, Tong M, Tang J, Bian H, Wan X, He L, Hou R 2019. Analysis of multiple pesticide residues in polyphenol-rich agricultural products by UPLC-MS/MS using a modified QuEChERS extraction and dilution method. Food Chemistry, 274.

DOI: https://doi.org/10.1016/j.foodchem.2018. 08.134

Kanda M, Djaneye-Boundjou G, Wala K, Gnandi K, Batawila K, Sanni A, Akpagana K. 2013. Application des pesticides en agriculture maraichère au Togo. VertigO, 13(1). DOI: https://doi.org/10.4000/vertigo.13456.

Kim KH, Kabir E, Jahan SA. 2017. Exposure to pesticides and the associated human health effects. Science of the Total Environment, 575: 525-535. DOI : https://doi.org/10.1016/j.scitotenv.2016. 09.009 .

Koala D, Ouattara L, Ouoba P, Bonzi S, Dabire 
TG, Somda I. 2018. Antifungal activity of the ethanolic extract of Berlinia grandifolia (Vahl) Hutch. \& Dalz. on the major phytopathogenic fungi of seeds. International Journal of Innovation and Applied Studies, 29 (1): 491-499.

Konate M, Parkouda C, Tarpaga V, Guira F, Rouamba A, Sawadogo-Lingani H. 2017. Evaluation des potentialités nutritives et l'aptitude à la conservation de onze variétés d'oignon (Allium cepa L.) bulbe introduites au Burkina Faso. International Journal of Biological and Chemical Sciences, 11(5): 2005-2015. DOI:

https://doi.org/10.4314/ijbcs.v11i5.6

Lehman E, Turrero N, Kolia M, Konaté Y, De Alencastro L F. 2017. Dietary risk assessment of pesticides from vegetables and drinking water in gardening areas in Burkina Faso. Science of the Total Environment, 601-602: 1208-1216. DOI https://doi.org/10.1016/j.scitotenv.2017. 05.285

Licciardi S, Assogba-Komlan F, Sidick I, Chandre F, Hougard JM, Martin T. 2007. A temporary tunnel screen as an ecofriendly method for small-scale farmers to protect cabbage crops in Benin. International Journal of Tropical Insect Science, 27(3-4): 152-158. DOI: https://doi.org/10.1017/S1742758407883 184

Ngom S, Manga A, Diop M, Thiam MB, Rousseau J, Cissé I, Traoré S. 2013. Etude de l'évaluation des résidus de pesticides dans les produits horticoles de grande consommation au Sénégal. Revue.

Ivoirienne des Sciences et Technologie, 21\&22: 31-44. DOI: https://doi.org/10.1016/S03044017(96)01152-1

Ouédraogo R, Ilboudo S, Bayili B, Pare T, Kekele A, Sawadogo B, Ouedraogo JB. 2016. Utilisation des pesticides agricoles dans trois régions à l'ouest du burkina faso et evaluation de leur impact sur la sante et l'environnement : cas des régions de la boucle du mouhoun, des cascades et des hauts-bassins. Centre National de la Recherche Scientifique et Technologique (CNRST) - Direction régionale de l'Ouest / Convention de rotterdam. http://www.pic.int/Portals/5/download.as px?d=UNEP-FAO-RC-Workshop-

BurkinaFaso-Report-201212.Fr.pdf.

Ouedraogo RA, Koala M, Dabire C, Hema A, Bazie VBEJT, Outtara L, Gnoula C, Pale E, Nebie RHC. 2015. Teneur en phénols totaux et activité antioxydante des extraits des trois principales variétés d'oignons (Allium cepa L.) cultivées dans la région du Centre-Nord du Burkina Faso. International Journal of Biological and Chemical Sciences, 9(1): 281. DOI: https://doi.org/10.4314/ijbcs.v9i1.25

Toé AM. 2010. Étude pilote des intoxications dues aux pesticides agricoles au Burkina Toé AM. 2010. Étude pilote des intoxications dues aux pesticides agricoles au Burkina Faso. In Secrétariat de la Convention de Rotterdam, FAO 94 p. Disponible sur www.pic.int/Portals/5/download. aspx?d=UNEP-FAO-RC-SHPFsPilotstudyBurkina.Fr.pdf.

Sawadogo RV. 2016. Pratiques paysannes d'utilisation des pesticides en cultures maraîchères et leurs effets induits dans la Vallée du Sourou: Cas du périmètre de Di. Memoire de fin de cycle, Institut du Developpement Rural (I.D.R), Universite Polytechnique De Bobo-Dioulasso (U.P.B) p. 33.

Shafiwu AB, Donkoh SA, Alhassan H. 2018. Consumers' preferred purchasing outlet of safer vegetables in Ouagadougou, Burkina Faso. Cogent Food \& Agriculture, 4(1): 1-15. DOI: https://doi.org/10.1080/23311932.2018.1 489714

Son D, Somda I, Legreve A, Schiffers B. 2017. Pratiques phytosanitaires des producteurs de tomates du Burkina Faso et risques pour la santé et l'environnement. Cahiers Agricultures, $\quad \mathbf{2 6}(2) . \quad$ DOI: https://doi.org/10.1051/cagri/2017010

Son D, Zerbo FKB, Bonzi S, Legreve A, Somda I, Schiffers B. 2018. Assessment 
of tomato (Solanum lycopersicum 1.) producers' exposure level to pesticides, in Kouka and Toussiana (Burkina Faso). International Journal of Environmental Research and Public Health, 15(2). DOI : https://doi.org/10.3390/ijerph15020204

Tarnagda B, Guira F, Sourabié PB, Zongo O, Tapsoba F, Zongo C, Drabo KM, Traoré Y, Savadogo A. 2019. Evaluation of heavy metals and pesticides contents in market-gardening products sold in some principal markets of Ouagadougou (Burkina Faso). Journal of Microbiology, Biotechnology and Food Sciences, 8(4): 1026-1034.

DOI:

https://doi.org/10.15414/jmbfs.2019.8.4. 1026-1034

Tarnagda B, Tankoano A, Tapsoba F, Sourabié $\mathrm{PB}$, Abdoullahi HO, Djbrine AO, Drabo KM, Traore Y, Savadogo A. 2017. Évaluation des pratiques agricoles des légumes feuilles: le cas des utilisations des pesticides et des intrants chimiques sur les sites maraîchers de Ouagadougou, Burkina Faso. Journal of Applied Biosciences, 117: 11658-11668. DOI: https://doi.org/10.4314/jab.v117i1.3

Tiendrebeogo A, Ouedreaogo I, Bonzi S, Kassankognon AI. 2017. Etude de l'activité antifongique d'extraits de Cymbopogon citratus (DC.) Stap, Eclipta alba L., Lippia multiflora M. et Agave sisalana P. Internationnal Journal of Biological and Chemical Sciences, 11(3): 1202-1211

Ullah R, Malik RN, Muhammad A, Ahad K, Tariq M, Asghar R, Qadir A. 2016. Higher Concentrations and Ecological Risks of Selected Persistent Organic Pollutants in Macrobrachium lamarrei from the Streams of Sialkot, Pakistan. Journal of Agricultural Science and Technology B, 6(1): 27-34. DOI: https://doi.org/10.17265/21616264/2016.01.004

Wognin A, Ouffoue S, Assemand E, Tano K, Koffi-Nevry R. 2014. Perception des risques sanitaires dans le maraîchage à Abidjan, Côte d'Ivoire. International Journal of Biological and Chemical Sciences, $\quad 7(5)$ : $1829 . \quad$ DOI: https://doi.org/10.4314/ijbcs.v7i5.4. 